\title{
NUCLEAR ENERGY INFORMATION FLOW FROM DOE TO THE PUBLIC
}

\author{
J. L. Simmons \\ W. L. Rankin \\ S. M. Nealey
}

JUNE 1980

Work performed under contract DE-AC06-76RLO 1830

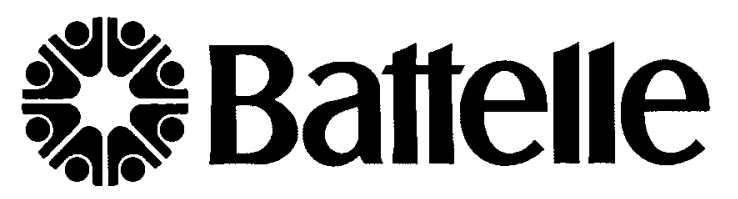

Human Affairs Research Centers

4000 N.E. 41st Street $\bullet$ Seattle, Washington 98105 


\section{Legal Notice}

This report was prepared by Battelle as an account of sponsored research activities. Neither Sponsor nor Battelle nor any person acting on behalf of either: (a) Makes any warranty or representation, express or implied, with respect to the accuracy, completeness, or usefulness of the information contained in this report or that the use of any information, apparatus, process, or composition disclosed in this report may not infringe privately owned rights; or (b) Assumes any liabilities with respect to the use of, or for damages resulting from the use of, any information, apparatus, process, or composition from the use of, any inform
disclosed in this report. 
PNL -3159

B/HARC/411/014

33679000537706 $\mathrm{UC}-70$

NUCLEAR ENERGY INFORMATION FLOW

FROM DOE TO THE PUBLIC

\author{
J. L. Simmons \\ W. L. Rankin \\ S. M. Nealey
}

June, 1980

\footnotetext{
Prepared for the Waste Management Systems Studies Program of the Pacific Northwest Laboratory of the U.S. Department of Energy under contract DE-AC06-76RLO 1830
}

\footnotetext{
Battelle Memorial Institute Human Affairs Research Center Social Change Study Center Energy and Environment Program Seattle, Washington 98105
} 
Executive Summary . . . . . . . . . . . . . . . . . . iv

Introduction . . . . . . . . . . . . . . . . . . . . . . 1

Study Approach . . . . . . . . . . . . . . . . . . . 3

Interviews ... . . . . . . . . . . . . . . 3

Written Material .. . . . . . . . . . . . . 4

Readability Tests.................... 4

Results . . . . . . . . . . . . . . . . . . . . . . . 7

DOE Organizational Structure and Objectives (Task 1)

Field offices . . . . . . . . . . . . . . 9

National offices.................. . . 10

Office of Consumer Affairs . . . . . . . . . 11

Office of Intergovernmental Affairs. . . . . . . 12

Public Affairs . . . . . . . . . . . 13

Readability Study (Task 2) . . . . . . . . . . . . 14

Public Attitude Versus DOE Perceptions of Public Attitudes • . 17

NonDOE Energy Information Programs........... 19

Conclusions and Recommendations . . . . . . . . . . . . . 21

References . . . . . . . . . . . . . . . . . . . 23

Appendix A. Standard Interview Questions............ . 25

Appendix B. Readability Test Results . . . . . . . . . . . 31 


\section{LIST OF TABLES}

Page

Table 1. DOE Regional offices . . . . . . . . . . . . . . . . . . 9

Table 2. Summary of Readability Test Results . . . . . . . . . . . 15

Table 3. Flesch Readability Ratings for Several Contemporary Magazines . . . . . . . . . . . . . . . . . . . . 16

Table 4. Nuclear Knowledge and Nuclear Attitudes Public Opinion Versus DOE Perception. . . . . . . . . . . . . . . . . 18

Table B-1. Readability Test Results . . . . . . . . . . . . . 35

LIST OF FIGURES

Page

Figure 1. Department of Energy . . . . . . . . . . . . . . . 8 
The objective of this research was to study the DOE's program for educating the public about nuclear power and nuclear waste management. We studied DOE's organizational structure and the procedures used within this structure to disseminate information and conducted readability tests on nuclear information distributed by DOE. Initial information was obtained through interviews with 29 local, state, and federal DOE representatives. This was supplemented with additional information as it was released by the DOE.

The overall goal of the DOE is to direct the United States' energy future by providing the framework for a comprehensive, balanced, national energy plan with primary emphasis placed on conservation. The primary goals of the DOE's information program are to encourage two-way communication between the DOE and the public and to encourage public participation in policy-making decisions.

Most of this communication, however, is presented orally, especially in the case of nuclear waste management information. Relative to other energy technologies and conservation, very few nuclear brochures are currently being distributed by the DOE. This is especially true with regard to information about nuclear waste. Yet a recent public survey found that a majority of the public wants to learn more about nuclear power and that, with regard to the nuclear fuel cycle, the public wants most to learn about nuclear waste management. Thus, the DOE appears to be missing an eager audience. 
The information being disseminated by DOE about nuclear power and nuclear waste management is dull and difficult to read. A readability test applied to this information indicated that a minimum of 14 years of education would be needed in order to fully comprehend this material. Since only about 15 percent of the United States population over 17 years of age has that much education, the present material is destined to reach a small part of the population. Information targeted for a ninth or tenth grade level could be comprehended by over 80 percent of the United States population over 17 years of age and would also be useful in the high schools and perhaps adaptable for grade school use.

Finally, DOE public affairs staff believe that relative to other news sources the public trusts government sources the least to provide unbiased information about nuclear power and nuclear waste management. Contrary to this belief, however, are public survey findings that the public trusts government sources more than the news media, environmentalist groups, or utility companies. Perhaps this trust, and the above-discussed desire for more nuclear waste management information, ought to be responded to by DOE via easily understood descriptive information about DOE's waste management plans. 
INTRODUCTION

The objective of this research was to study the Department of Energy's (DOE) program for educating the public about nuclear power. Specifically, we tried to answer the question "How does information flow from DOE to the public?" DOE's organizational structure and the procedures used within this structure to disseminate information were analyzed. We collected nuclear information distributed by DOE, then determined the readability level of this material. This report describes the technical approach, results, and conclusions and recommendations from this study of nuclear information flow.

This study is part of a larger Nuclear Waste Communications Program sponsored by the DOE under the direction of the Pacific Northwest Laboratory (PNL). The mission of the overall on-going program is to inform the DOE about the processes by which nuclear waste management information reaches the public and the anticipated effects of this information. 
To achieve the goals of this study, two tasks were initiated:

(1) identify the organizational structure of DOE's information program, and (2) conduct a readability analysis of DOE's information. We then compared the results of this study to the results of other studies. In addition, we identified the emphasis/needs of information programs of several utility companies associated with the Edison Electric Institute. These specific tasks are more fully described in this section while the results of the study are provided in the following section.

\section{INTERVIEWS}

Because of the DOE's newness when this study began, very little written information was available that detailed activities of the departments with which we were concerned. Therefore, we obtained our initial information through interviews with 29 local, state, and federal DOE representatives. We supplemented this with additional information as it was released by DOE.

During the interviews we asked each representative several questions concerning: (1) the objectives of the DOE program with which they were concerned; (2) their intended audience for their program information; (3) their information dissemination process; and (4) the subject of their information. We then asked questions (about perceived public desires regarding nuclear power information) to compare DOE perceptions with the actual information desired by the public according to Nealey and Rankin. (1) After the DOE representatives responded, we gave them the results of the Nealey and Rankin ${ }^{(1)}$ study to provide feedback regarding differences between perceived and actual public information needs. 
WRITTEN MATERIAI

During the inverviews, we gathered as much publicly available nuclear information as possible. We then conducted readability studies on this information which was, for the most part, in brochure format. To compare DOE nuclear information with other publicly available nuclear information, we also collected samples from the Atomic Industrial Forum and the Edison Electric Institute. We then conducted readability tests on these publications.

\section{READABILITY TESTS}

Since DOE's public information programs are directed to the average nontechnical person, we conducted two readability tests to determine whether the DOE is distributing material geared to this reading level. (NOTE: all material had been prepared by DOE's predecessor, ERDA.) We used the Gunning Fog Index ${ }^{(2)}$ to measure the readability level and the Flesch Readability Test ${ }^{(3)}$ to determine the level of interest.

Both readability tests are based on word and sentence length. The Gunning Fog Index uses a multiplication factor to make the index represent the approximate years of schooling needed to readily comprehend the information. Thus, a high Fog Index means that the material is difficult to understand. The steps for the two tests are listed below.

\section{Gunning Fog Index}

Step 1. Take a sample of at least 100 words. (a) Determine the average number of words per sentence.

Step 2. Count the number of polysyllables (words of three syllables or more) per 100 words.

Step 3. Add the average number of words per sentence to the polysyllable percentage and multiply the sum by 0.4 .

(a) For both tests we started our 100-word samples with the fourth and eleventh paragraphs. 
The Flesch Test

Step 1. Select a 100-word sample.(b)

Step 2. Determine the average sentence length.

Step 3. Determine the average word length (syllables per word).

Step 4. Determine the average number of personal sentences (sentences containing personal pronouns such as you, we, etc.).

Step 5. Find the readability and interest levels by referring to Flesch's tables. (3)

The results of this analysis are presented in the following section of this report.

(b) For both tests we started our 100-word samples with the fourth and eleventh paragraphs. 

The overall goal of the DOE can best be explained by quoting President Carter in his presidential statement on the Department of Energy's activation: "The creation of a Department of Energy is an important step toward dealing with our energy problems. It will give clear direction and focus to our energy future by providing the framework for carrying out a comprehensive, balanced national energy plan. This will help the public and private sectors as they work together to bring energy supply and demand back into balance--both now and for the years ahead." (4)

With this goal in mind, many individuals and organizations have been combined into a single unit, the DOE. Although they have been combined, these organizations still have very distinct functions. These functions, particularly in the area of nuclear waste information dissemination, were the concern of our study.

DOE ORGANIZATIONAL STRUCTURE AND OBJECTIVES (TASK 1)

The first step to understanding how nuclear information flows from DOE to the public was to understand the internal structure of DOE, its objectives, and activities. From our interviews we learned that the DOE is divided into various organizational levels (see Figure 1). The Assistant Secretaries at the federal level oversee the general functions of DOE. The main information objectives at this level, as determined by our interviews, are to help the public realize that there is an energy cris is and that conservation is a must in our energy programs. The message is conservation, and the means of getting this message to the 
F1gure I

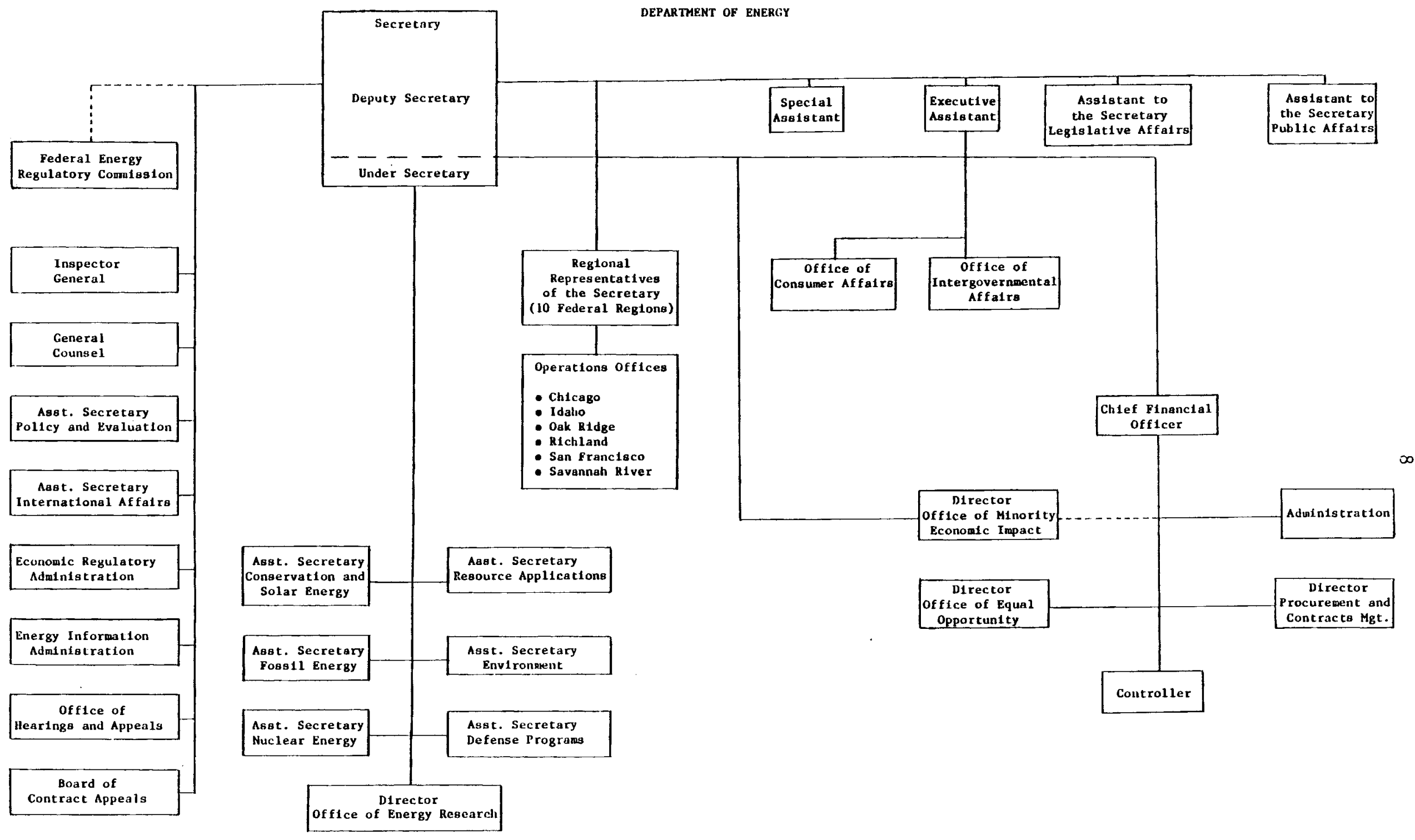


public is through brochures, meetings, television and radio spots, and one-to-one town-type meetings. The general attitude is one of trying to encourage the public to participate on its own.

\section{Fie1d offices}

The regional and field operations are overseen by the Regional Representatives and the Operations offices. The interests of these individuals are related to their specific missions. For example, if they deal with waste management, their concerns are to tell people about waste management. Through all representatives, though, runs a feeling of the need to communicate with the average citizen, to tell the real energy story. Credibility is a major concern of all people we talked to, and most DOE representatives interviewed underestimated their credibility with the public.

The DOE's field structure takes into account the diversity of the field programs and geographical dispersion of the field installations. As a result, ten regional offices have been established (see Table 1 ).

\section{TABLE 1}

DOE Regional offices

\begin{tabular}{ll}
\hline Region & \multicolumn{1}{c}{ Location } \\
\hline 1 & Boston, MA \\
2 & New York, NY \\
3 & Philadel Phia, PA \\
4 & Atlanta, GA \\
5 & Chicago, IL \\
6 & Dallas, TX \\
7 & Kansas City, MO \\
8 & Lakewood City, CO \\
9 & San Francisco, CA \\
X & Seattle, WA \\
\hline
\end{tabular}


Each region is responsible for several tasks:

- speaking for the Secretary and all Department activities in the region,

- working with the governors of each state,

- assuring effective regional outreach programs, including interaction with regional business, labor, and consumer groups, and appropriate involvement of regional groups in departmental decision making,

- providing feedback to the Department on the impact of department policies and programs, and

- performing assigned nonregulatory tasks in regional planning, conservation, energy resource development, and energy data collection.

These Regional Representatives report to the Secretary (see

Figure 1), and the Office of Intergovernmental Affairs assists the Secretary in directing and supporting the Regional Representatives. The Operations offices provide a formal link between Department headquarters and the field laboratories and other facilities. These offices are located in Chicago, Illinois; Albuquerque, New Mexico; Idaho Falls, Idaho; Las Vegas, Nevada; Oak Ridge, Tennessee; Richland, Washington; San Francisco, California; and Savannah River, Georgia.

\section{National offices}

At the national level, public information about energy is handled by several different organizations within the DOE (see Figure 1). Involved are the Office of Consumer Affairs and the Office of Intergovernmental Affairs, both of which report to the Executive Assistant to the Secretary, and the staff of the Assistant to the Secretary for Public Affairs. The purpose of these organizations is to establish two-way communications regarding energy matters with target groups such as state 
and local governments, business and industry, consumers, special interest groups, and individual citizens. This allows the organizations to provide direct support to the Secretary and his policy and management staffs and to provide guidance and assistance on external relations to program staffs at both the national and field levels. The role of these organizations is public information and public education and not that of advocating positions on programs of the DOE.

Each office has disseminated specific information to a specific audience. This line of communication is open both ways; thus the public can go directly to each office for information or they can go to the Regional Representative, the Operations Offices or, if they like, even the prime contractors.

Some of the major duties of these offices are:

- providing an organizationally high level, visible point of contact for particular public and private individuals and groups, and facilitating their communication with appropriate DOE offices,

- informing citizens, groups and other entities of programs, services, and publications available within the DOE,

- informing the Secretary and other top management of events, views, interests, and impacts outside the Department which might affect DOE policies and programs, and

- developing policies and procedures for ensuring feedback to the DOE on target group reactions to these policies and programs.

Office of Consumer Affairs. The Department's contact with the public and with a variety of special interest groups is the Office of Consumer Affairs. Its objective is to involve the public in forming national policy by arranging for public meetings to stimulate two-way communication. These meetings, called Consumer Briefings, enable the public to talk to national energy makers. The first Consumer Briefing 
dealt with nuclear issues, including nuclear waste management, and information was transferred verbally in a question and answer session. Another important function of the office of Consumer Affairs is to prepare and distribute a newsletter, which includes, among other things, important waste management policy decisions, to help people to stay abreast of current DOE events.

Departmental interactions with educational institutions, business and industrial communities, organized labor, trade associations, and professional societies and organizations are also coordinated through the Office of Consumer Affairs. Workshops, refresher courses, and other teaching situations are the main forms of interactions with these groups.

Office of Intergovernmental Affairs. The office of Intergovernmental Affairs handles DOE's interactions with state and local governments, and with national associations of state and local officials. The objective of this office is to provide the technology to help industry and government save energy and use substitute energy sources. This information is generally transferred to industry and government officials on a one-to-one basis and in written reports.

of particular interest to our study was the Energy Extension Service operated by this office. The purpose of this service is to design and implement energy-related activities aimed at increasing energy savings and substituting renewable for nonrenewable energy sources. Currently this pilot program is operational in ten states: Alabama, Connecticut, Michigan, New Mexico, Pennsylvania, Tennessee, Texas, Washington, Wisconsin, and Wyoming. This cooperative federal/state effort is funded through federal grants, but it is expected to soon spread to 50 states 
and six territories with $50 / 50$ federal and state funding. These programs have been designed and are administered by each state, not by the DOE. Finally, the relations with Native American tribes, who own important energy resources, are handled by this office. Due to the nature of this office's objectives, no nuclear waste information was transmitted to the public during the study period.

Public Affairs. Departmental communications with the news media and the general public are handled through Public Affairs. This office also oversees all departmental activities in the development and distribution of informational materials. Their objective is to alert people to the energy problem and to translate for a general audience DOE research and the effect it will have on people. Most of the publicly available nuclear waste information originates from this office, but very little of such information has been prepared. Of the 200 news releases reviewed during our interview period, seven dealt with nuclear information but none with nuclear waste management. Most nuclear waste information is transmitted in town-type meetings and through reports that are publicly available but are written for a technical audience.

To keep timely and accurate information flowing to the general public and the media, Public Affairs prepares or has prepared for them brochures and handouts, movies, slide shows, exhibits, and newsmedia information. Audio visuals also play another important part in the Public Affairs communication programs including motion pictures, workshops, and slide presentations. Interactive displays (i.e., displays that are programmed to exchange information with the public) are the backbone of the exhibits program and are placed in museums, science centers, fairs, etc. 


\section{READABILITY STUDY (TASK 2)}

From Task 1 we learned that the main goal of the DOE representatives is to give their audience an overview of their respective areas of responsibilities. Thus, their information must be readable for their intended audience. On the federal and regional levels, the intended audience is the general public which has little technical knowledge and, on the average, has less than a high school education. Due to the nature of their work, the operations and contractor representatives deal with a more select group such as peers or federal sponsors, but in many cases the level of technical knowledge is still very low.

To determine whether DOE is reaching this goal, we conducted readability tests on the publicly available nuclear information distributed by the DOE; the readability tests are described in the Technical Approach section of this report. In the seven publicly available nuclear brochures distributed by DOE, the average Fog Index was 16 (see Table 2). This means that to easily comprehend the material, one would need the reading level of a person with four years of college, which is the case for less than 15 percent of the general public. The Flesch Test indicated that all of the samples were "extremely difficult" to read and that none had a high level of interest.

To put these readability levels into perspective, refer to Table 3 , which has been adapted from a table in Flesch's book How to Test

Readability $^{(3)}$ (see Appendix B for a detailed comparison of the study results and Flesch's table). From Table 3 it can be seen that academic, scientific, and professional-type magazines are rated as extremely difficult. Yet DOE's information, being distributed to the general 


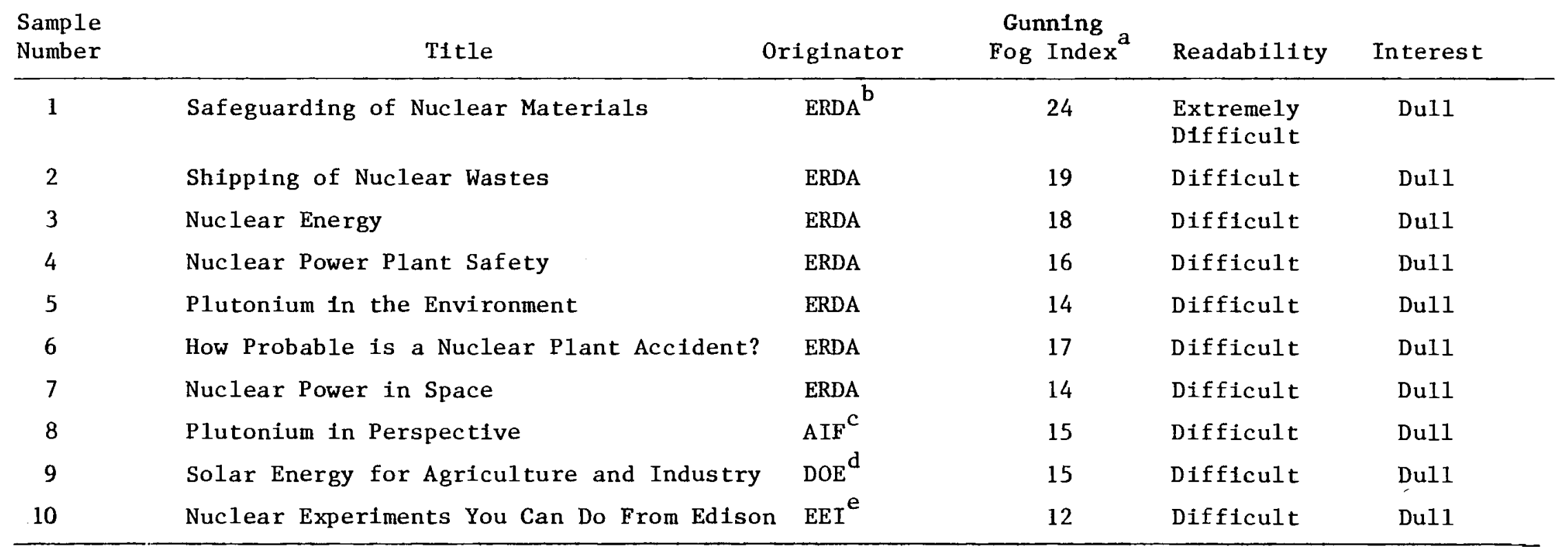

${ }^{a}$ Number of years of school necessary for understanding.

${ }^{b}$ Energy Research and Development Administration.

Atomic Industrial Forum.

$\mathrm{d}_{\text {Department of Energy. }}$

${ }^{e}$ Edison Electric Institute. 
public at fairs, visitor centers, etc., carries the same ratings.

However, two points must be noted: (1) all of the nuclear brochures were prepared by ERDA, not DOE, even though DOE is distributing them; and (2) these readability tests are only guidelines aned should serve as indicators, not mandatory rules.

TABLE 3

Flesch Readability Ratings for Several Contemporary Magazines

\begin{tabular}{ll}
\hline \multicolumn{1}{c}{ Typical Magazine } & Description of Style \\
\hline Comics & Very Easy \\
Pulp Fiction & Easy \\
Slick Fiction & Fairly Easy \\
Digests, Time, Mass Nonfiction & Standard \\
Harper's, Atlantic & Fairly Difficult \\
Academic, Scholarly & Difficult \\
Scientific, Professional & Very Difficult \\
\hline
\end{tabular}

To determine if other types of information have been written in a more understandable and interesting way, we sampled a DOE-prepared brochure on solar energy technology. It too had a high Fog Index of 15 and was extremely difficult and dull (see Table 2). We also sampled a nuclear brochure produced and distributed by the Atomic Industrial Forum (AIF) and another nuclear publication by the Edison Electric Institute (EEI). According to the Flesch Test, these samples were also difficult and uninteresting. However, the Gunning Test (Fog Index) did indicate that the EEI publication was the most readable, with a reading level of 12. Thus some nuclear information has been prepared for a larger portion 
of the public. However, if the goal of the DOE information program is to write for the average public, their material should be rewritten to achieve a reading level of ninth or tenth grade. Approximately 80 percent of the American public over 17 years of age would be able to read such material.

PUBLIC ATTITUDE VERSUS DOE PERCEPTIONS OF PUBLIC ATTITUDES

As we stated earlier in this section, DOE is setting up commication channels with the public. To provide input to DOE about its perception of how the public gets nuclear information, how it feels about government information, and what kind of information the public wants, we asked three attitude questions (the last three question in Appendix A) during our interviews. We then compared this information to Nealey and Rankin's survey of nuclear knowledge and attitudes. (1)

Our study indicated that the majority of DOE representatives thought that the public got most of its information from television and that the government was the least used source of information (see the first part of Table 4). But, according to Nealey and Rankin, Washington State residents get most of their information from (1) newspapers, (2) television, (3) news magazines, (4) government sources, and (5) environmental sources. Thus, DOE representatives somewhat underestimated their importance as an information source.

of the given information sources, the DOE representatives thought that the public somewhat trusted television ( 2.2 on Table 4$)$, environmental groups (2.4), news magazines and newspapers (2.5), and they felt that government sources were somewhat distrusted (3.7). However, according to Nealey and Rankin, the public distrusts, to some extent, all 
TABLE 4

Nuclear Knowledge and Nuclear Attitudes

Public Opinion Versus DOE Perception

\begin{tabular}{lll}
\hline & $\begin{array}{c}\text { DOE } \\
\text { Representatives }\end{array}$ & $\begin{array}{c}\text { Washing ton State } \\
\text { Residents }\end{array}$ \\
\hline SOURCE OF INFORMATION & & 5 \\
Environmental groups & 4 & 4 \\
Governmental sources & 5 & 3 \\
News magazines & 3 & 1 \\
Newspapers & 2 & 2 \\
Television & 1 & 3.6 \\
TRUST LEVEL & & 3.2 \\
Environmental groups & 2.4 & $3.4^{\mathrm{d}}$ \\
Governmental sources & 3.7 & $3.4^{\mathrm{d}}$ \\
News magazines & 2.5 & $3.4^{\mathrm{d}}$ \\
Newspapers & 2.5 & \\
Television & 2.2 & 4 \\
NEED MORE INFORMATION & & 5 \\
Fuel fabrication & 4 & 2 \\
Mining and miliing & 5 & 3 \\
Reactor operation & 2 & 1 \\
Reprocessing & 3 & \\
Waste management & 1 & 5 \\
\hline
\end{tabular}

anformation is provided in ranked order where $1=$ the most public information source and $5=$ the least used source.

${ }^{b}$ Average score where: 1 =strongly trusts; 2 = somewhat trusts; $3=$ neither trusts nor distrusts; 4 = somewhat distrusts; $5=$ strongly distrusts.

cInformation is provided in ranked order where 1 = the information most wanted and $5=$ the information least wanted by the public.

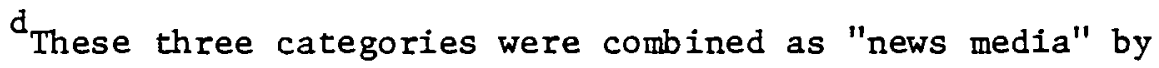
Nealey and Rankin. (1) 
news sources regarding nuclear energy information (3.4-3.6 on Table 4), but distrusts government sources the least (3.2). Further, DOE representatives thought that the public somewhat trusts (2.4) environmental groups, when in fact, they somewhat distrust (3.6) these groups.

DOE representatives were well aware of the kind of nuclear power information most desired by the public--waste management information. In fact, there was very good perception regarding the order of importance placed by the public on all five areas of the nuclear fuel cycle with regard to the desire for information.

\section{NonDOE Energy Information Programs}

We had established the fact that there was a lack of waste management information for the public. But we needed to better understand the concerns of the public utility companies in order to determine whether they would actually use DOE-prepared information. Thus, 15 persons were interviewed at the Edison Electric Institute's First Annual Conference of Electric Utility Educators in order to gain information regarding this question.

The main emphases of the EEI's First National Conference of Electric Utility Educators were energy education and rate justification. The participating utilities felt that their credibility with the public was going down but had not reached the depths of the oil companies. In an effort to halt and reverse this trend, many utilities have initiated or are initiating energy education programs. Most utility people at the conference felt that they should place a greater emphasis on working with teachers to develop such programs. 
The target audience for the energy education program appears to be grade school children. The general consensus was that this was the age least prejudiced by family and peers. High school, college, and adult audiences were considered to be too set in their ways, the most antagonistic, and the least receptive to energy education programs.

When asked what type of information they would like to receive from the DOE, most of the 15 respondents said more information on the alternative energy technologies. All persons interviewed felt that they had enough nuclear information, but at the same time, very few were aware of current waste management programs. This was particularly true for the representatives from nonnuclear utilities. It was interesting to note that all the interviewees had copies of the DOE and AIF brochures. In addition, all or most received the DOE's "Energy Insider" newspaper. Thus, it is apparent that a direct line of communication is already open between DOE and the utility companies. It is also apparent that the utility companies are trying to establish a direct line of communication between themselves and the public. 
CONCLUSIONS AND RECOMMENDATIONS

It was clearly evident from the first task of this study that DOE's overall objective is to unify the United States' approach to solving our energy problems. A key part of this unification is the establishment of a machanism in which the public, private, and federal sectors can effectively communicate.

The DOE has been organized with communication in mind. The energy information staffers at the federal level work closely with the Regional Representatives and Operations offices to establish two-way communication channels between the federal representatives and the public and private sectors. To date, however, this communication is mostly oral or, if written, it is for highly technical audiences such as research reports generated by the national laboratories. To be effective, the overall communication program should have written resource information available in forms that are understandable to semitechnical and nontechnical people.

At the time of this study, the DOE had prepared several brochures on alternative energy sources but none on nuclear waste management techniques and options. The consensus of DOE representatives' opinions was that they should wait for a federal energy policy statement before they prepare any information. At least one brochure on nuclear transportation has been prepared since our study. As was found by Nealey and Rankin, (1) however, Washington State residents most want nuclear waste management information and they trust the government more than other information sources; yet they are receiving most of their information from newspapers and other news media. If these findings can 
be generalized for the United States population as a whole, then we recommend that easily understood material (written for those with a ninth or tenth grade education), that merely describes the various nuclear waste management techniques be made publicly available to the news media for public dissemination. This resource material would also help teachers, information specialists, and utility companies in preparing their own nuclear waste management information programs, a need demonstrated by this study. A national policy statement need not be included in such educational material. DOE is the logical organization to prepare and distribute such credible, nontechnical, nuclear waste management information because DOE is most knowledgeable about nuclear waste management and already has its information channels in place.

Key communication channels already established include the DOE Energy Insider, ${ }^{(5)}$ the Office of Consumer Affairs' "town hall meetings," Regional Representatives' meetings with local officials, and news releases. These channels can also be used to disseminate any newly prepared educational material. Using these established channels will help to ensure that the nuclear waste management information will get to the people who need it. And, if the DOE prepares this information so that it is easily understandable for persons with a ninth or tenth grade education, those who want the waste management information will also be able to understand it. 


\section{REFERENCES}

1. S. M. Nealey, and W. L. Rankin, Nuclear Knowledge and Nuclear Attitudes: Is Ignorance B1iss? BHARC-411-002, Human Affairs Research Centers, Battelle Memorial Institute, Seattle, WA.

2. R. Gunning, How to Take the Fog out of Writing, The Dartnell Corporation, Chicago, IL, 1964 .

3. R. Flesch, How to Test Readability, New York, Harper, 1951.

4. President James Earl Carter, III, "Presidential Statement, Department of Energy Activation," Organization and Functions Fact Book, Department of Energy, September, 1977.

5. Energy Insider, Office of Public Affairs, U.S. Department of Energy, Washington, D.C. 

APPENDIX A

STANDARD INTERVIEW QUESTIONS 

APPENDIX A

STANDARD INTERVIEW QUESTIONS

Due to the newness of the DOE at the time this study began, very little written information was available that detailed activities of the departments with which we were concerned. Therfore, we obtained our initial information through interviews with 29 local, state, and federal DOE representatives. We supplemented this with additional information as it was released by DOE.

During the interviews we asked each representative several standard questions concerning: (1) DOE's objective, (2) the intended audience, (3) information dissemination process, and (4) the subject. These questions are:

- DOE's Objective

- What do you see as the overall objective of DOE's Information Program?

- What specific messages are you trying to get to the public?

- What are your plans for attaining this objective?

- Audience

- Who is the intended audience?

- What is their level of technical knowledge?

- Process

- How is the information disseminated to reach this audience?

- Content

- What percentage of your information is nuclear? 
The final three questions were asked in order to compare the actual information the public wants with what DOE perceives the public to want. These questions were:

- Perceived Information Sources

There are five sources of information about nuclear power that we are interested in: environmental groups, governmental sources, news magazines, newspapers, and television. We would like to know which of these sources you think the public uses the most to gain information about nuclear power. How would you rank these if " 1 " is the most-used public source and " 5 " is the least-used public source?

Environmental groups

Governmental sources

News magazines

L_ News papers

Television

- Trust Level

We would also like to know how much you think the public trusts these sources of information. Do you think that the public:

1 = strongly trusts, 2 = somewhat trusts, 3 = neither trusts nor

distrusts, 4 = somewhat distrusts, or 5 = strongly distrusts

these sources of information.

Environmental groups

Governmental sources

News magazines

News papers

Television 
- Desired Information

We would like to know what areas of the nuclear cycle you think that people want to learn more about. If "l" is the area that people want to learn most about, and " 5 " is the area that people want to learn least about, how would you rank the areas of the nuclear fuel cycle.

Fuel fabrication

Mining and milling

- Reactor operation

Reprocessing

Waste management

The responses to these questions are described in the results section of this report. 


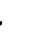


APPENDIX B

READABLITY TEST RESULTS 

APPENDIX B

READABILITY TEST RESULTS

Table B.1 provides the variables we obtained to determine the readability and interest levels of the DOE-distributed nuclear information as measured by the Gunning and Flesch Tests. To use Table B.1, compare Parts 1 and 2 of the Flesch Test. Note that in the Readability column, all of the samples in Part I are rated as "difficult" or "extremely difficult." To put these ratings in perspective, refer to Part II. The typical magazines with similar ratings (difficult) are academic, scholarly, scientific, and professional. The significance of this information is that although DOE is attempting to communicate with the general public (twelfth grade level), their material is written for an audience with a much higher education level. 

TABLE B-1

Readabl11ty Teat Result.

\begin{tabular}{|c|c|c|c|c|c|c|c|c|c|}
\hline \multirow[b]{2}{*}{ ritle } & \multirow[b]{2}{*}{ Originator } & \multicolumn{3}{|c|}{ GunnIng Yog Index" } & \multicolumn{5}{|c|}{ Fleoch Readabllity } \\
\hline & & $\begin{array}{c}\text { Words/ } \\
\text { Sentence }\end{array}$ & $\begin{array}{c}\text { Poly- } \\
\text { oyllables }\end{array}$ & $\begin{array}{c}\text { Fog } \\
\text { Index }\end{array}$ & $\begin{array}{l}\text { Worde/ } \\
\text { Sentence }\end{array}$ & $\begin{array}{l}\text { Syllablea/ } \\
100 \text { Hords }\end{array}$ & $\begin{array}{l}2 \text { Personal } \\
\text { Sentencea }\end{array}$ & Readabillty & Intere日t \\
\hline \multicolumn{10}{|l|}{ RATED MATERIAL } \\
\hline Safeguarding of Muclear Materiale & ERDA $^{b}$ & 26 & 35 & 24 & 25 & 236 & o & $\begin{array}{l}\text { Extremely } \\
\text { Difficult }\end{array}$ & Dul1 \\
\hline Stupplng of Huclear Wastes & ERDA & 26 & 23 & 19 & 25 & 186 & 0 & Difficult & Dull \\
\hline Nuclear Energy & ERDA & 26 & 20 & 18 & 25 & 183 & o & Difficult & Dull \\
\hline Huclear Pouer Plant Sufety & ERA & 22 & 18 & 16 & 22 & 187 & $\mathbf{0}$ & Difficult & Dull \\
\hline Plutonlum in the Environment & ERDA & 20 & 15 & 14 & 20 & 174 & 0 & Difficult & Dull \\
\hline Uow Prabablo 1s . Nuclear Plant Accident? & ERDA & 25 & 18 & 17 & 25 & 186 & .005 & Difficult & Das 11 \\
\hline Nuclear Power in space & ERDA & 15 & 20 & 14 & 17 & 184 & $\mathbf{0}$ & Diffleult & Dul1 \\
\hline Plutonlum in Perapective & $A I r^{c}$ & 18 & 19 & 15 & 18 & 184 & $\mathbf{0}$ & Difficult & Dull \\
\hline Solar Energy for Agriculture and Induatry & $\operatorname{DoE}^{d}$ & 22 & 17 & 15 & 22 & 176 & 0 & Difficult & Dull \\
\hline Nuclear Experimenta You Can Do Prom Ediaon & EEI $^{\mathbf{\theta}}$ & 15 & 11 & 12 & 15 & 168 & o & Difflcult & Dull \\
\hline \multicolumn{10}{|l|}{ EXAMPLES OF VLESCH READABXLITY RATINGS } \\
\hline $\cos i c$ & & & & & 8 & 123 & & Very Eainy & \\
\hline Pulp riction & & & & & 11 & 131 & & Easy & \\
\hline slick riction & & & & & 14 & 139 & & Falrly Easy & \\
\hline DIgeats, IIne, Mass Honfictlon & & & & & 17 & 141 & & Standard & \\
\hline Harper': Aclant1c & & & & & 21 & 155 & & Falrly Diffle & \\
\hline Academic, Scholarly & & & & & 25 & 161 & & Difficule & \\
\hline Scientific, Professional & & & & & 29 & 192 & & Very Difficul & \\
\hline
\end{tabular}

"ikuber of years of school neceasary for underatanding.

benergy Resescch and Development Adainlatration.

Atomlc Industrlal Porum.

departaent of Energy.

Edison Electric Inatitute.

IAdapted froo reference 6. 


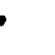




\section{DISTRIBUTION}

\begin{tabular}{ll} 
No. of & No. of \\
Copies & Copies \\
\hline
\end{tabular}

W. Ballard, Jr.

DOE Office of Energy Programs

Washington, D.C. 20545

D. L. Bodde

Office of Nuclear Policy

Energy Research

Washington, D.C. 20585

A. A. Churm

DOE Chicago Patent Group

9880 South Cass Avenue

Argonne, IL 60439

J. Cohen

Lawrence Livermore Laboratory

Livermore, CA 94550

T. Cotton

Office of Technology Assessment

Washington, D.C. 20510

27 DOE Technical Information Center

P.O. Box 62

Oak Ridge, TN 38730

C. H. George

DOE Office of Nuclear

Was te Management

Washington, D.C. 20545

T. Greenwood

Office of Science Technology Policy

Washington, D.C. 20500

G. Grave

Los Alamos Scientific

Laboratory

Los Alamos, NM 87544

C. A. Heath

DOE Office of Nuclear

Waste Management

Washington, D.C. 20545

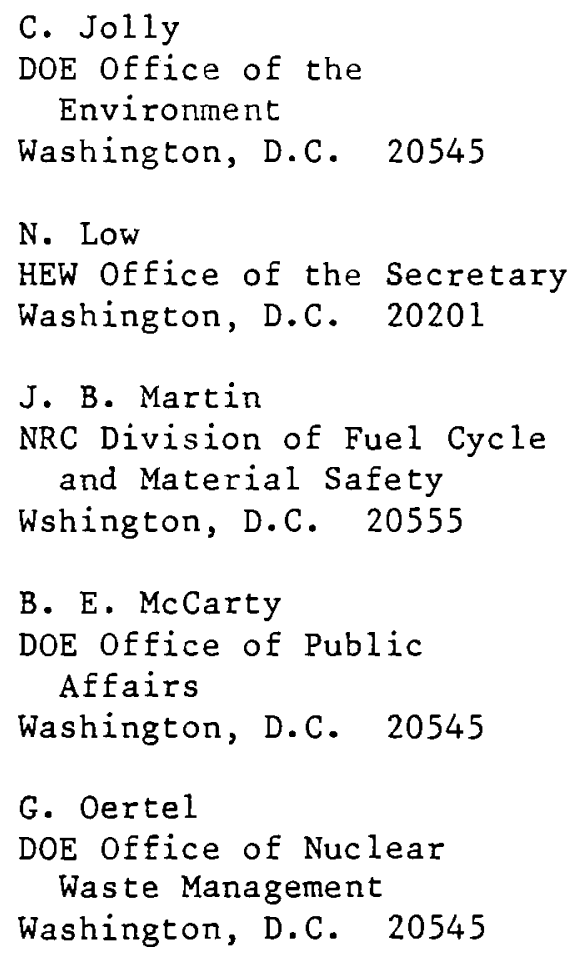

S. L. Topp

Savannah River Laboratory Aiken, SC 29801 
No. of

Copies

T. C. Hobson

DOE Office of Consumer Affairs

Washington, D.C. 20545

V. G. Trice

DOE Office of Nuclear

Was te Management

Washington, D.C. 20545

E. F. Mastal

DOE Office of Nuclear Waste Management

Washington, D.C. 20545

J. W. Rowen

DOE Office of Nuclear

Was te Management

Washington, D.C. 20545

$\underline{\text { Richland Operations Office }}$

3 Contract office

P. A. Craig

O. J. Elgert

Office of Nuclear Waste

Isolation

N. Carter

D. Keller

Pacific Northwest Laboratory

5 Technical Files

2 Publishing Coordination

D. E. Olesen

J. B. Burnham

D. E. Deonigi

R. P. Marshall

M. R. Kreiter

A. M. Platt

3 J. V. Robinson
No. of

Copies

Beverly Rawles

Battelle - ONWI

Columbus, $\mathrm{OH} 43201$

M. J. Lawrence

DOE Office of Nuclear

Waste Management

Washington, D.C. 20545

E. J. Wahlquist

DOE Office of Nuclear

Was te Management

Washington, D.C. 20545
H. E. Ransom

J. J. Schreiber

M. W. Shupe 